\title{
HUBUNGAN FAKTOR KONDISI SANITASI LINGKUNGAN DAN PERSONAL HYGIENE DENGAN GEJALA SKABIES DI PONDOK PESANTREN DARUL HIKAM KECAMATAN RIMBO ULU KABUPATEN TEBO TAHUN 2021
}

\author{
Friska Indriani', Guspianto', Fitria Eka Putri ${ }^{1}$ \\ ${ }^{1}$ Program Studi IImu Kesehatan Masyarakat, FKIK Universitas Jambi
}

\begin{abstract}
Scabies is a skin disease caused by Sarcoptes scabei Var hominis. This disease commonly occurs in tropical countries with densely populated areas and low economic conditions. This study aims to determine the relationship between environmental sanitation conditions and personal hygiene factors towards the symptoms of scabies in Darul Hikam Islamic Boarding School, Rimbo Ulu Sub-district, Tebo District. This observational study used a cross-sectional design. This study used an observational method with a cross-sectional design, population as many as 400 respondents and sample as many as 63 respondents taken by proportionate strafied random sampling. The results of this study showed that $71.4 \%$ of respondents experienced symptoms of scabies; $93.7 \%$ of the respondent provided clean water facilities that met the requirements; $66.7 \%$ of residential density did not meet the requirements; $50.8 \%$ of the ventilation area did not meet the requirements; $71.4 \%$ of the respondent showed poor skin hygiene; $61.9 \%$ of the respondent showed poor towel hygiene; and $55.6 \%$ of the respondent showed poor mattress and bed sheet hygiene. The analysis indicates a relationship between residential density $(p=0.008)$, ventilation area $(p=0.000)$, skin cleanliness $(p=0.038)$, towel cleanliness $(0.036)$, and mattress and bed sheet cleanliness $(p=0.049)$ with symptoms of scabies at Darul Hikam Islamic Boarding School. Residential density, ventilation area, skin cleanliness, towel cleanliness, and mattress and bed sheet cleanliness are related to scabies symptoms, while the provision of clean water facilities is not related.
\end{abstract}

\section{Keywords : Symptoms of scabies, Environmental Sanitation, Personal Hygiene}

\begin{abstract}
ABSTRAK
Skabies adalah penyakit kulit yang disebabkan oleh Sarcoptes scabei Var hominis. Skabies rentan terjadi di negara beriklim tropis, daerah padat penduduk dan ekonomi rendah. Penelitian ini bertujuan untuk mengetahui hubungan faktor kondisi sanitasi lingkungan dan personal hygiene terhadap gejala skabies di Pondok Pesantren Darul Hikam Kecamatan Rimbo Ulu Kabupaten Tebo. Metode penelitian dengan desain Cross Sectional, Populasi sebanyak 400 responden dan sampel sebanyak 63 responden diambil dengan teknik Proporsionate Strafied Random Sampling. Teknik analisis data dengan menggunakan uji statistik chi-square. Hasil Penelitian didapatkan terdapat $71,4 \%$ responden mengalami gejala skabies, 93,7\% penyediaan sarana air bersih yang memenuhi syarat, 66,7\% kepdatan hunnian yang tidak memenuhi syarat, 50,8\% luas ventilasi yang tidak memenuhi syarat, $71,4 \%$ kebersihan kulit yang buruk, 61,9\% kebersihan handuk yang buruk dan 55,6\% kebersihan kasur dan sprei yang buruk, ada hubungan antara kepadatan hunian $(p=0,008)$ luas ventilasi $(p=0,000)$ kebersihan kulit $(p=0,038)$ kebersihan handuk $(0,036)$ dan kebersihan kasur dan seprei $(p=0,049)$ dengan gejala skabies di Pondok Pesantren Darul Hikam. Kepadatan hunian, luas ventilasi, kebersihan kulit, kebersihan handuk, kebersihan kasur dan sprei, berhubungan dengan gejala skabies sedangkan penyediaan sarana air bersih tidak berhubungan.
\end{abstract}

Kata kunci: Gejala skabies, Sanitasi Lingkungan, Personal Hygiene 


\section{PENDAHULUAN}

Skabies merupakan penyakit menular di daerah tropis dan subtropis yang disebabkan oleh Parasit Sarcoptes scabiei varian homini. Penyakit ini dapat menyebar secara langsung maupun tidak langsung dari satu orang ke orang lain. Skabies bisa ditemukan di wilayah yang padat penduduk, tempat yang kumuh, sanitasi yang tidak baik, kurangnya air bersih, kurangnya hidup bersih serta kurangnya gizi dan vitamin yang dapat memicu penyakit skabies tersebut ${ }^{1}$.

Skabies ditandai dengan gejala seperti gatal-gatal diarea tubuh pada saat malam hari yang disebut priritus nokturna. Gatal tersebut dikarenakan adanya sensitivitas eksret dan sekret dari tungau, setelah satu bulan terinfeksi kulita yang gatal akan ditandai dengan bintikbintik merah. Bagian tubuh dengan stratum korneum tipis rentan terhadap penyakit ini, bagian tubuh itu meliputi pergelangan tangan, sela-sela jari, siku luar, ketiak tengah, paha, alat reproduksi luar pada pria, dan sekitar payudara wanita. ${ }^{2}$

Skabies dapat memberikan dampak seperti gangguan masalah sosial yang berkaitan dengan citra tubuh, sehingga orang yang terkena skabies kurang percaya diri akibat luka garukan yang membekas. Kemudian membuat orang merasa tidak nyaman, menggangu konsentrasi belajar sehingga tidak fokus saat proses belajar. Selain itu skabies juga mempengaruhi kualitas tidur, kualitas tidur ini akan membuat penderita merasa pusing pada keesokan harinya dan gangguan ingatan. $^{3}$

Berdasarkan data World Health Organization (2020), skabies bisa menyerang $10 \%$ anak-anak di daerah miskin, penyakit ini dapat menyerang semua orang di setiap negara. Skabies rentan terjadi di negara beriklim tropis, dan skabies banyak terjadi di daerah padat penduduk dan ekonomi rendah. Menurut WHO, kejadian skabies pada tahun 2020 dapat mempengaruhi lebih dari 200 juta orang setiap saat, prevalensi penyakit skabies dalam literatur terkait kudis baru-baru ini berkisar dari $0,2 \%$ hingga $71 \%{ }^{4}$

Menurut Departemen Kesehatan Republik Indonesia (2013) prevalennsi penyakit kulit diseluruh indonesia ditahun 2012 sebanyak 8,46\% kemudian menigkat di tahun 2013 sebesar $9 \%$, sehingga skabies menduduki urutan ke 3 dari 12 penyakit kulit tersering di Indonesia.6 Pada tahun 2015 kejadian skabies juga cukup tinggi di beberapa negara, salah satunya adalah Indonesia dengan prevalensi sebesar 3,9-6\%, hal ini karena Indonesia merupakan negara tropis. Prevalensi skabies di Indonesia setiap tahun nampaknya terus menurun, meskipun prevalensinya menurun skabies masih menjadi masalah penyakit menular yang serius di Indonesia. ${ }^{5}$

Laporan dari Dinas Kesehatan Provinsi Jambi tahun 2018 skabies merupakan penyakit kulit ke-4 tertinggi dengan persentase sebesar 29,5\%. ${ }^{6}$ Kabupaten Tebo merupakan salah satu wilayah di Provinsi Jambi yang kejadian skabies tersebar luas di setiap daerah. Menurut status kesehatan Kabupaten Tebo, terlihat pada tahun 2015 penyakit kulit telah menjadi 10 penyakit dengan kejadian tertinggi yaitu sebanyak 7.268 kasus. $^{7}$

Puskesmas Rimbo Bujang IX yang terletak di Kabupaten Tebo memiliki angka kejadian penyakit kulit pada tahun 2018 sebanyak 940 kasus, dan pada tahun 2019 sebanyak 925 kasus. $^{8}$ Pondok Pesantren Darul Hikam merupakan pondok pesantren yang terletak di 
wilayah kerja Puskesmas Rimbo Bujang IX Diantara Pondok Pesantren yang berada di wilayah kerja puskesmas Rimbo Bujang IX, Pondok Pesantren Darul Hikam merupakan Pondok Pesantren paling banyak siswanya mengalami gatal-gatal, bintik-bintik merah di pergelangan tangan dan sela jari di antara Pondok Pesantren yang lainnya.

Berdasarkan survey awal yang dilakukan di Pondok Pesantren Darul Hikam, pada tahun 2018 sebanyak 50 kasus santri yang mengalami gatal-gatal, bintik-bintik merah di

\section{METODE}

Jenis penelitian yang digunakan pada penelitian ini yaitu penelitian observasional yang menggunakan pendekatan kuantitatif dengan rancangan penelitian cross sectional yang bertujuan untuk mengetahui hubungan antara faktor risiko (independen) dengan akibat atau efek (dependen) yang mana pengumpulan data dilakukan dalam satu waktu antara variabel independen dengan dependen.

Penelitian dilaksanakan di Pondok Pesantren Kecamatan Rimbo Ulu Kabupaten Tebo pada bulan April 2021. Populasi pada penelitian ini berjumlah 400 orang mencakup seluruh santri di Pondok Pesantren Darul pergelangan tangan dan sela jari yang menyerupai gejala skabis sedangkan pada tahun 2019 sebanyak 46 kasus, para santri akan melapor ke pengurus pondok jika mereka merasa sudah tidak bisa menahan rasa gatalnya lagi. ${ }^{9}$

Berdasarkan latar belakang tersebut peneliti tertarik untuk mengkaji hubungan faktor kondisi sanitasi lingkungan dan personal hygiene dengan gejala skabies di Pondok Pesantren Darul Hikam Kecamatan Rimbo Ulu Kabupaten Tebo.

Hikam Kecamatan Rimbo Ulu Kbaupaten Tebo. Pengambilan sampel menggunakan teknik proportionate strafied random sampling yang dipilih dari proporsi masing-masing kelas yang memenuhi kriteria inklusi dan eksklusi yang berjumlah 63 sampel. Teknik analisis data dengan menggunakan uji statistik chi square.

\section{HASIL}

Berdasarkan hasil penelitian tentang hubungan faktor kondisi sanitasi lingkungan dan personal hygiene dengan gejala skabies di Pondok Pesantren Darul Hikam Kecamatan Rimbo Ulu Kabupaten Tebo didapatkan karakteristik responden yang ditunjukkan pada tabel dibawah ini:

Tabel 1. Analisis Univariat

\begin{tabular}{lcc}
\hline Variabel & Frekuensi & Persentase (\%) \\
\hline Gejala Skabies & 45 & 71,4 \\
Gejala & 18 & 28,6 \\
Tidak Gejala & & \\
\hline Sarana Penyediaan Air Bersih & 4 & 6,3 \\
Tidak Memenuhi Syarat & 59 & 93,7 \\
Memenuhi Syarat & & \\
\hline Kepadatan Hunian & 42 & 66,7 \\
Tidak Memenuhi Syarat & 21 & 33,3 \\
Memenuhi Syarat & & \\
\hline
\end{tabular}




\begin{tabular}{lcc}
\hline uas Ventilasi & 32 & \\
Tidak Memenuhi Syarat & 31 & 50,8 \\
Memenuhi Syarat & & \\
\hline Kebersihan Kulit & 45 & 71,4 \\
Buruk & 18 & 28,6 \\
Baik & & \\
\hline Kebersihan Handuk & 39 & 61,9 \\
Buruk & 24 & 38,1 \\
Baik & & \\
\hline Kebersihan Kasur dan Sprei & 35 & 55,6 \\
Buruk & 28 & 44,4 \\
Baik & &
\end{tabular}

Berdasarkan tabel 2 diatas dapat diketahui bahwa sebanyak $71,4 \%$ responden mengalami gejala skabies, 93,7\% responden yang penyediaan sarana air bersihnya memenuhi syarat, $66,7 \%$ responden yang tinggal di kamar dengan kepadatan hunian yang tidak memenuhi syarat, 50,8\% responden yang tinggal dikamar dengan luas ventilasi yang tidak memenuhi syarat, $71,4 \%$ responden yang memiliki kebersihan kulit yang buruk, $61,9 \%$ responden dengan kebersihan handuk yang buruk dan 55,6\% responden dengan kebersihan kasur dan sprei yang buruk.

Hasil penelitian menggunakan analisis bivariat untuk mengetahui apakah ada hubungan antara faktor kondisi sanitasi ingkungan dan personal hygiene dengan gejala skabies di Pondok Pesantren Darul Hikam Kecamatan Rimbo ulu Tahun 2021. Adapun uji yang digunakan yaitu uji statistik chi-square dengan batas kemaknaan $\alpha<0,05$. Dikatakan ada hubungan yang signifikan secara statistik jika diperoleh nilai $p$ value $<0,05$.

Tabel 3. Analisis Bivariat

\begin{tabular}{|c|c|c|c|c|c|c|c|c|}
\hline \multirow{3}{*}{ Variabel } & \multicolumn{6}{|c|}{ Gejala Skabies } & \multirow{3}{*}{$\begin{array}{c}\mathbf{P} \\
\text { Value }\end{array}$} & \multirow{3}{*}{$\begin{array}{c}\text { PR } \\
(95 \% \mathrm{Cl})\end{array}$} \\
\hline & \multicolumn{2}{|c|}{ Gejala } & \multicolumn{2}{|c|}{ Tidak Gejala } & \multicolumn{2}{|c|}{ Total } & & \\
\hline & $\mathbf{n}$ & $\%$ & $\mathbf{n}$ & $\%$ & $\mathbf{n}$ & $\%$ & & \\
\hline \multicolumn{9}{|l|}{ Penyedian Sarana } \\
\hline \multicolumn{8}{|l|}{ Air Bersih } & \multirow{4}{*}{$\begin{array}{r}1,844 \\
(0,635- \\
5,531)\end{array}$} \\
\hline Tidak Memenuhi & 2 & 500 & 2 & 500 & 4 & 100 & 0,571 & \\
\hline Syarat & 2 & U, & $c$ & U, & 4 & 100 & & \\
\hline Memenuhi syarat & 43 & 72,9 & 16 & 27,1 & 69 & 100 & & \\
\hline \multicolumn{8}{|l|}{ Kepadatan Hunian } & \multirow{4}{*}{$\begin{array}{c}8,500 \\
(1,212- \\
59,599)\end{array}$} \\
\hline \multirow{3}{*}{$\begin{array}{l}\text { Tidak Memenuhi } \\
\text { Syarat } \\
\text { Memenuhi Syarat }\end{array}$} & & & & & & & \multirow{3}{*}{0,008} & \\
\hline & 25 & 59,5 & 17 & 40,5 & 42 & 100 & & \\
\hline & 20 & 95,2 & 1 & 4,8 & 21 & 100 & & \\
\hline \multicolumn{7}{|l|}{ Luas Ventilasi } & \multirow{3}{*}{\multicolumn{2}{|c|}{$\begin{array}{l}0,057 \\
(0,008- \\
0,403)\end{array}$}} \\
\hline Tidak Memenuhi & 31 & 966 & 1 & 31 & 33 & 100 & & \\
\hline Syarat & & & & & & & & \\
\hline
\end{tabular}




\begin{tabular}{|c|c|c|c|c|c|c|c|c|}
\hline \multirow{2}{*}{ Memenuhi Syarat } & \multirow{2}{*}{14} & \multirow{2}{*}{45,4} & \multirow{2}{*}{17} & \multirow{2}{*}{54,8} & \multirow{2}{*}{30} & \multirow{2}{*}{100} & \\
\hline & & & & & & & & \\
\hline Kebersihan Kulit & & & & & & & 0,038 & 0,400 \\
\hline Buruk & 36 & 80,0 & 9 & 20 & 45 & 100 & & $(0,190-$ \\
\hline Baik & 9 & 50,0 & 9 & 50 & 18 & 100 & & $0,842)$ \\
\hline \multicolumn{9}{|l|}{ Kebersihan } \\
\hline Handuk & & & & & & & & 0,392 \\
\hline Buruk & 32 & 82,1 & 7 & 17,9 & 39 & 100 & 0,036 & $(0,176-0$ \\
\hline Baik & 13 & 54,2 & 11 & 45,8 & 24 & 100 & & 871) \\
\hline $\begin{array}{l}\text { Kebersihan Kasur } \\
\text { dan Snrei }\end{array}$ & & & & & & & & 0,400 \\
\hline Buruk & 29 & 82,9 & 6 & 17,1 & 35 & 100 & 0,049 & $(0,172-$ \\
\hline Baik & 16 & 57,1 & 12 & 42,9 & 28 & 100 & & $0,931)$ \\
\hline
\end{tabular}

Sumber: Data Primer 2021

Berdasarkan uji statistik pada tabel 3 didapatkan nilai $\mathrm{p}$ value $>0,05$ pada penyediaan sarana air bersih $(p=0,571), p$ value $<0,05$ pada kepadatan hunian $(p=0,008)$, luas ventilasi $(p=0,000)$, kebersihan kulit $(p=0,0038)$, kebersiha handuk $(0,036)$ dan kebersihan kasur dan

\section{PEMBAHASAN}

1. Gejala Skabies

Hasil penelitian menunjukkan bahwa gejala skabies pada santri menunjukkan bahwa sebagian besar responden mengalami gejala skabies sebanyak 45 santri $(71,4 \%)$, diantaranya 32 responden laki-laki (97,0\%) mengalami gejala skabies dan 13 (43,3\%) responden perempuan mengalami gejala skabies.

Laki-laki memiliki risiko terkena penyakit skabies lebih tinggi dari pada perempuan. Hal ini dikarenakan skabies sering terjadi pada alat kelamin pria, kemudian wanita lebih memperhatikan kesehatannya dibandingkan pria. Alat kelamin adalah tempat lesi yang paling umum, karena tungau skabies lebih mudah membuat terowongan pada stratum korneum yang lembab dan tersembunyi. Bentuk skabies adalah gumpalan. sprei $(p=0,049)$ yang menunjukkan bahwa terdapat hubungan yang bermakna antara kepdatan hunian, luas ventilasi, kebersihan kulit, kebersihan handuk dan kebersihan kasur dan sprei dengan gejala skabies di Pondok Pesantren Darul Hikam Kecamatan Rimbo Ulu Kabupaten Tebo.

Skabies biasanya terdapat pada area tertutup, alat kelamin pria, selangkangan, inguinal dan aksila. $^{10}$

Gejala yang timbul pada skabies menunjukkan bahwa lebih dari setengah responden mengalami gejala, yaitu : rasa gatal yang berasal dari bintik bintik kecil yang terdapat pada kulit sebanyak 53 orang $(84,1 \%)$. sedangkan sebagian kecil responden gejalanya, yaitu : Rasa gatal yang dialami rasanya (Panas atau terbakar) sebanyak 30 santri $47,6 \%$.

Skabies merupakan parasit inflamasi yang disebabkan oleh tungau (Sarcoptes scabiei). Kutu betina hamil menggali ke dalam kulit dan bertelur 2-3 telur per hari selama sekitar satu bulan. ${ }^{11}$ Tanda dan gejala adalah proritus nocturna, yakni gatal pada malam hari, penyakit ini menyerang orang dalam kelompok, muncul sebagai salah satu luka khas dalam 
bentuk terowongan (Kurunikurus). Tempat predileks berwarna putih atau abu-abu, garis lurus atau berliku-liku, dengan panjang ratarata $1 \mathrm{~cm}$. Jerawat dan folikel dapat terlihat di ujung terowongan, di mana tempat predileksnya adalah kulit keratin tipis, yaitu, pada jari, pergelangan tangan, lipatan siku bagian luar, areola (perempuan), pusar, pantat, dan alat kelamin luar (laki-laki). dan perut bagian bawah. Pada bayi dapat mempengaruhi telapak tangan atau telapak kaki. ${ }^{12}$

Banyak faktor yang mendorong perkembangan skabies, termasuk status sosial ekonomi yang buruk, kebersihan yang buruk, hubungan seksual, kesalahan diagnosis, perkembangan penyakit kulit atau patogen. ${ }^{13}$ Penularan dapat terjadi, karena: kontak langsung kulit dengan kulit penderita skabies, seperti menjabat tangan, hubungan seksual, tidur bersama. Kontak tidak langsung yang berkelanjutan (melalui barang) seperti berbagi tempat tidur, pakaian, menyewa handuk dan barang-barang pribadi lainnya yang harus berbagi dengan teman-teman. ${ }^{14}$ Untuk itu diharapkan bagi santri dapat meningkatkan pengetahuan tentang pencegahan dan penularan penyakit kulit skabies.

\section{Hubungan Sarana Penyediaan Air Bersih} dengan Gejala Skabies di Pondok Pesantren Darul Hikam

Hasil penelitian menunjukkan bahwa tidak ada hubungan yang signifikan antara sarana penyedian air bersih dengan gejala skabies pada santri di Pondok Pesantren Darul Hikam Kecamatan Rimbo Ulu Kabupaten Tebo dengan $p$ value $>\alpha$ yang mana $55,1 \%$ santri memperoleh fasilitas penyedian sarana air bersih yang memenuhi standar persyaratan dan menunjukkan nilai prevalence ratio (PR) sebesar 1,844 dengan nilai $(\mathrm{Cl}=95 \%)$, menunjukkan bahwa responden yang tidak mendapatkan penyediaan sarana air bersih yang tidak memenuhi syarat memiliki resiko 1,844 kali mengalami gejala skabies.

Hal ini sejalan dengan penelitian Fitria, dkk 2020 yang mendapatkan hasil penelitian bahwa tidak ada hubungan antara penyediaan sarana air bersih dengan keluhan penyakit skabies ( $p$ value $=0,725) \cdot{ }^{15}$ Hasil yang sama juga di dapatkan oleh Nadiya, dkk 2018 yang menunjukkakn bahwa berdasarkan hasil uji statistik didapatkan nilai $p$-value $=-$ terlihat tidak ada hubungan yang signifikan antara penyediaan sarana air bersih dengan penyakit skabies. ${ }^{16}$

Sarana penyediaan air bersih adalah bangunan, sarana dan bahan yang memproduksi, menyediakan dan mendistribusikan air kepada masyarakat. Ada berbagai jenis fasilitas penyediaan air yang digunakan masyarakat untuk memasok dan mengumpulkan air sesuai kebutuhan seharihari. Air yang diperoleh di fasilitas ini berasal dari tiga sumber yang ada di alam: air permukaan, air tanah dan air hujan. Pengolahan air yang umum digunakan untuk keperluan rumah tangga meliputi sumur limbah, penampungan air hujan, sumur pompa, PDAM, sumber pelindung, jaringan pipa dan terminal air. $^{17}$

Salah satu yang termasuk dalam sanitasi lingkungan adalah penyediaan air bersih. Air merupakan kebutuhan yang paling penting untuk kelangsungan hidup manusia, oleh karena itu diperlukan air yang kualitasnya memenuhi syarat kesehatan. Air yang tidak memenuhi syarat kesehatan dapat sebagai media penularan penyakit, salah satunya penyakit skabies. Seseorang dapat terkena 
penyakit skabies jika mandi di air yang kotor, dimana air kotor tersebut telah tercemar. ${ }^{18}$

Berdasarkan hasil observasi menunjukkan bahwa sarana air bersih di pondok pesantren darul hikam menggunakan sumur bor dan perpipaan. Kondisi penyedian sarana air bersih di pondok pesantren darul hikam kecamatan rimbo ulu sudah memenuhi standar persyaratan kesehatan. Hal ini di dukung dari hasil penelitian yang didapatkan dari observasi menunjukkan bahwa tidak ada jamban terdekat berupa jamban lubang tanpa saluran menembus tanah, tidak ada sumber pencemaran lain (kotoran hewan, sampah dll), tidak ada kerusakan pada saluran pembuangan air sehingga air tidak tergenang, sumur disegel dengan aman, par tidak rusak, air tidak dapat meresap ke rumah pompa, kotak pemecah tekanan tidak kotor, penampungan air yang digunakan dilengkapi dengan penutup.

Sarana penyedian air bersih yang memenuhi syarat faktor resiko terkena skabiesnya lebih kecil di bandingkan dengan penyediaan sarana air bersih yang tidak memenuhi syarat karena penyediaan air bersih berhubungan dengan air sebagai media penularan penyakit. Bak air kolah yang digunakan bersama-sama lebih berpotensi menularkan skabies yang dapat terjadi apabila air yang masuk ke tubuh melalui kulittercemar oleh kotoran, termasuk tungau yang dapat memicu terjadinya skabies. ${ }^{19}$

3. Hubungan Kepadatan Hunian dengan Gejala Skabies di Pondok Pesantren Darul Hikam

Berdasarkan analisis bivariat menggunakan uji Chi-square untuk mengetahui hubungan antara variabel kepadatan hunian dengan kejadian gejala skabies di Pondok Pesantren Darul Hikam Kecamatan Rimbo Ulu diperoleh nilai $\mathrm{p}=0,008<0,05$ yang diartikan bahwa ada hubungan antara kepadatan hunian dengan gejala skabies di Pondok Pesantren Darul Hikam Kecamatan Rimbo Ulu dan menunjukkan nilai prevalence ratio (PR) sebesar 8,500 dengan nilai $\mathrm{Cl}$ 95\%, menunjukkan bahwa responden yang tinggal di asrama dengan kepadatan hunian yang tidak memenuhi syarat memiliki resiko 8,500 kali mengalami gejala skabies

Penelitian ini didukung oleh hasil penelitian Ramadlon, dkk 2017 mengatakan bahwa ada hubungan antara kepadatan hunian dengan kejadian skabies, dengan nilai $p$ value $0.021<$ 0.05.68. Hal ini sejalan dengan penelitian Ayu pada tahun 2018 berdasarkan hasil dari analisa statistik dengan menggunakan uji Chi-Square diperolehnilai $P$ Value $=0,001<0,05$ hal ini menunjukan hahwa adanya hubungan kepadatan hunian dengan kejadian skabies. ${ }^{20}$

Menurut Permenkes RI No. 1077/Menkes/Per/V/2011 tentang Pedoman Penyehatan Udara kepadatan hunian yang memenuhi syarat satu orang menempati luas minimal $8 \mathrm{~m} 2$ untuk mencegah penyebaran penyakit. Ukuran rumah yang tidak sesuai dengan jumlah orang, dapat menyebabkan kepadatan penduduk. Semakin padat populasi dalam ruangan, semakin cepat udara dalam ruangan tercemar. Peningkatan kadar $\mathrm{CO} 2 \mathrm{di}$ udara dalam ruangan meningkatkan kemungkinan bakteri tumbuh dan berkembang biak. $^{21}$

Hal ini didukung ketika peneliti mengamati dan mengukur ukuran kamar santri. Banyak kamar yang sempit ditempati oleh dua orang atau lebih, Didapatkan distribusi frekuensi bahwa $66,7 \%$ santri tinggal di asrama dengan kepadatan hunian yang tidak memenuhi persyaratan. 
Berdasarkan penelitian di lapangan kepadatan hunian di dua bangunan pondok laki-laki dan pondok perempuan Darul Hikam, dapat dikatakan bahwa hampir separuh lebih asrama di pondok pesantren memiliki kepadatan hunian yang tidak memenuhi syarat. Salah satu faktor yang mempengaruhi kepadatan hunian yang tidak memenuhi syarat adalah ketersediaan satu kamar perempuan $(9 \mathrm{~m} \times 5 \mathrm{~m})$ yang dihuni oleh 22 santri yang di dalamnya terdapat lemari kasur dan barangbarang para santri yang menyebabkan kondisi kamar menjadi pengap dan lembab sedangkan untuk kamar laki-laki hanya berukuran $(6,5 \mathrm{~m} x$ $3 \mathrm{~m}$ yang dihuni oleh 7 santri. Hal ini sudah menjadi ketetapan untuk menempati kamarkamar pondok pesantren. Jumlah hunian ruangan yang dihuni lebih dari kapasitas akan mengakibatkan suhu ruangan naik karena pengeluaran panas, dan kelembaban tubuh naik karena uap air yang dihasilkan selama respirasi atau penguapan cairan tubuh dari kulit. $^{21}$

Kondisi kepadatan yang tidak memenuhi syarat tersebut dikarenakan sempitnya ruangan, dan penghuninya bersifat kolektif, sehingga skabies lebih mudah berkembang biak di dalam ruangan dan lebih menular. Pihak puskesmas sebaiknya memberikan nasehat dan pengetahuan tentang kriteria hunian di mana minimal satu orang menempati $8 \mathrm{~m} 2$ kepada pengurus pondok pesantren. Oleh karena itu, untuk mencegah penyebaran lebih lanjut dari skabies ini, sangat penting untuk memperhatikan kepadatan hunian.

4. Hubungan Luas Ventilasi dengan Gejala Skabies di Pondok Pesantren Darul Hikam

Berdasarkan analisis bivariat menggunakan uji Chi-square untukmengetahui hubungan antara variabel luas ventilasi dengan gejala skabies di Pondok Pesantren Darul Hikam Kecamatan Rimbo Ulu diperoleh nilai $p=0,000$ $<0,05$ yang diartikan bahwa ada hubungan antara luas ventilasi dengan gejala skabies di Pondok Pesantren Darul Hikam Kecamatan Rimbo Ulu dan menunjukkan nilai $\mathrm{PR}<1$ dengan nilai $(\mathrm{Cl}=95 \%)$ yang berarti luas ventilasi yang memenuhi syarat sebagai faktor protektif. Hal ini juga terlihat pada distribusi frekuensi sebanyak $52,4 \%$ santri tinggal di ruangan yang ventilasi ruangannya tidak memenuhi syarat. Ventilasi merupakan lubang dan udara yang selalu ada di dalam rumah. Sistem ventilasi ini dapat memindahkan udara masuk dan keluar. ${ }^{21}$

Penelitian ini didukung oleh temuan Sari Yuanita (2015), menunjukkan bahwa ada hubungan antara luas ventilasi dengan kejadian skabiesNdengan nlai p adalah 0,035 < $0,05 .{ }^{22}$ Penelitian ini sejalan dengan penelitian yang dilakukan oleh Siti, dkk (2017) yang menunjukan hasil statistik nilai $p$ value $0.015<$ 0.05 menunjukkan bahwa ada hubungan antara luas ventilasi dengan kejadian skabies. ${ }^{23}$

Menurut Permenkes RI No. 1077/Menkes/Per/V/2011 tentang Pedoman Penyehatan Udara 2011 menunjukkan bahwa syarat luas ventilasi yang sesuai adalah minimal $10 \%$ serta mengatakan bahwa pertukaran udara yang buruk dan tidak memenuhi syarat dapat menyebabkan pertumbuhan mikroorganisme yang dapat menyebabkan gangguan kesehatan manusia. Bakteri dapat bertahan hidup didalam rumah apabila ventilasi di rumah sangat minim. Ventilasi yang tidak memadai akan menyebabkan kelembaban udara di dalam ruangan, penguapan. ${ }^{21}$ 
Berdasarkan observasi di lapangan faktor yang mempengaruhi kurangnya luas ventilasi pada kamar santri adalah ruangan kamar yang kecil, sebagian besar jendela di kamar laki-laki jarang terbuka, kemudian ventilasi pada kamar perempuan yang dibuat seperti jendela dan letaknya terlalu tinggi dan susah untuk dibuka. Kondisi ventilasi yang tidak memenuhi syarat sanitasi ini menyebabkan kurangnya cahaya matahari yang masuk dan pertukaran udara dalam kamar yang tidak memadai mengakibatkan bertumbuhnya bakteri-bakteri patogen penyebab penyakit, terutama penyakit skabies. ${ }^{21}$

Tanpa pertukaran udara yang baik, jumlah dan konsentrasi bakteri akan meningkat dan meningkatkan risiko penularan penyakit. Untuk itu puskesmas sebaiknya memberikan saran kepada pengurus pondok pesantren mengenai syarat rumah sehat yang memenuhi syarat yaitu $10 \%$ dari luas lantai, area ventilasi diperlukan untuk sirkulasi udara yang cukup. Oleh karena itu, ventilasi rumah terutama pada kamar santri perlu ditambahkan jumlahnya. ${ }^{21}$

5. Hubungan Kebersihan Kulit dengan Gejala

Skabies di Pondok Pesantren Darul Hikam Kecamatan Rimbo Ulu

Berdasarkan analisis bivariat menggunakan uji Chi-square untuk mengetahui hubungan antara variabel kebersihan kulit dengan gejala skabies di Pondok Pesantren Darul Hikam Kecamatan Rimbo Ulu diperoleh nilai $p=0,038$ $<0,05$ yang diartikan bahwa ada hubungan antara kebersihan kulit dengan gejala skabies di Pondok Pesantren Darul Hikam Kecamatan Rimbo Ulu, hal ini juga dapat dilihat dari distribusi frekuensi yaitu sebanyak $71,4 \%$ santri memiliki kebersihan kulit yang buruk dan menunjukkan nilai prevalence ratio (PR) sebesar 0,400 dengan nilai $\mathrm{Cl} 95 \%$, menunjukkan bahwa nilai $\mathrm{PR}<1$ yang berarti kebersihan kulit yang baik sebagai faktor protektif.

Hal ini sesuai dengan penelitian Ridwan dkk tahun 2017 di Pondok Pesantren Darul Muhlisin Desa Kendari, dimana terdapat hubungan $p=$ 0,005 antara kebersihan kulit dengan kejadian skabies. ${ }^{5}$ Pada tahun 2018, Ayu melakukan penelitian mengenai kebersihan kulit dengan gejala skabies dimana nalisis chi-square menunjukkan bahwa kejadian dispepsia berhubungan dengan personal hygiene $(P=$ $0,049) \cdot{ }^{20}$

Kulit merupakan lapisan terluar tubuh, termasuk organ dalam tubuh manusia. Peran kulit adalah menstabilkan tubuh dan membuang kotoran dan zat sisa dari dalam tubuh. Zat yang tersisa menjadi keringat dan dikeluarkan dari pori-pori kulit. Oleh karena itu, sangat penting untuk menjaga kesehatan kulit setiap saat. Salah satunya adalah menjaga kebersihan yang baik, merawat kulit terlihat sehat dan tidak terlihat kusam. Pentingnya menjaga kesehatan kulit yaitu, agar tidak terkena bakteri, kuman, virus, alergi, dll dan menderita berbagai penyakit kulit. ${ }^{24}$

Berdasarkan hasil wawancara dengan santri dan hasil distribusi pertanyaan mengenai kebersihan kulit banyak santri yang tidak memiliki alat mandi sendiri-sendiri jadi saat mandi mereka menggunakan alat mandi bergantian dengan temannya, mereka menggunakan sabun milik teman mereka $74,6 \%$, Penggunaan sabun secara bergantian dapat menyebarkan penyakit melalui kontak tidak langsung sabun merupakan benda yang selalu santri gunakan untuk membersihkan diri. Kemudian banyak santri yang telibat dalam kegiatan olah raga atau kegiatan lainnya yang 
mengeluarkan keringat dan segera mandi setelah selesai kegiatan tersebut $73,0 \%$. Hal inilah yang menjadi salah satu penyebab menularnya penyakit skabies pada santri. Santri dengan kebersihan kulit yang buruk lebih berisiko terkena penyakit kulit dibandingkan dengan santri dengan kebersihan kulit yang baik.

Untuk itu sebaiknya santri menggunakan jenis sabun cair dari pada sabun batangan, meskipun keduanya dapat membersikan tubuh dengan baik namun sabun batangan lebih berisko dari pada sabun cair. Hal ini karena jika sabun batang digunakan oleh beberapa orang bakteri pada sabun akan berpindah pada tubuh berbeda halnya dengan sabun cair yang memiliki kemasan dan tertutup rapat dan tidak mudah terkontaminasi oleh bakteri, dan dikemas dalam botol sehingga praktis dalam hal penyimpananya. ${ }^{25}$ Kemudian santri sebaiknya mandi setelah melakukan pendinginan sekitar 20-30 menit setelah berolahraga, agar keringat pada tubuh sudah mengering. Dalam menjaga kebersihan kulit dapat memperhatikan hal-hal seperti menggunakan peralatan sendiri untuk keperluan sehari-hari, mandi minimal $2 x$ sehari, mandi dengan sabun menjaga kebersihan pakaian dan memotong kuku. ${ }^{26}$

6. Hubungan Kebersihan Handuk dengan Gejala Skabies di Pondok Pesantren Darul Hikam Kecamatan Rimbo Ulu

Berdasarkan analisis bivariat menggunakan uji Chi-square untuk mengetahui hubungan antara variabel kebersihan handuk dengan gejala skabies di Pondok Pesantren Darul Hikam Kecamatan Rimbo Ulu diperoleh nilai $\mathrm{p}=0,036<0,05$ yang diartikan bahwa ada hubungan antara kebersihan handuk dengan gejala skabies di Pondok Pesantren Darul
Hikam Kecamatan Rimbo Ulu dan menunjukkan nilai prevalence ratio (PR) sebesar 0,392 dengan nilai $\mathrm{Cl} 95 \%$, menunjukkan bahwa nilai $\mathrm{PR}<1$ yang berarti kebersihan handuk yang baik sebagai faktor protektif, hal ini juga dapat dilihat dari distribusi frekuensi yaitu sebanyak $61,9 \%$ santri memiliki kebersihan handuk yang buruk. Santri dengan kebersihan handuk yang buruk lebih berisiko terkena penyakit kulit dibandingkan dengan santri dengan kebersihan kulit yang baik.

Hal ini sejalan dengan penelitian Ayu tahun 2018 dan variabel kebersihan handuk yang diteliti dengan analisis chi-square yang menunjukkan bahwa skabies berhubungan dengan kebersihan handuk, ${ }^{20}$ hasil yang sama dengan penelitian Ridwan, dkk 2017 menunjukkan hubungan antara kebersihan handuk dengan kejadian skabies di pondok pesantren Darul Muhlisin Kota Kendari dengan $\mathrm{p}=0,005 .^{5}$

Handuk adalah cara yang efektif untuk menyebarkan Tungau skabies dewasa dan telurnya dapat menempel pada kulit. Handuk yang terkontaminasi tungau dan telurnya dapat menyebarkan penyakit skabies ke orang yang menggunakannya. Handuk yang tidak bersih atau berganti-ganti tanpa dicuci dengan baik dapat meningkatkan aktivitas tungau Sarcoptes scabiei pada handuk. ${ }^{27}$

Tungau Sarcoptes scabiei senang hidup di tempat yang lembab. Jika handuk bekas mandi tidak dijemur, maka handuk tersebut akan menjadi lembab yang kemungkinan besar menjadi sarana rantai kehidupan tungau. ${ }^{26}$ Kebersihan handuk bisa menjadi media penularan penyakit skabies melalui kontak tidak langsung. ${ }^{3}$

Berdasarkan hasil wawancara kepada santri pada saat penelitian dan dari hasil distribusi 
pertanyaan mengenai kebersihan kulit menunjukkan bahwa lebih dari sebagian santri pada saat mencuci handuk tidak direnam menggunakan air panas terlebih dahulu dengan presentase $72,6 \%$, banyak santri menggunakan handuk dalam kondisi lembab dengan presentase $72,6 \%$ karena mereka hanya menggantungkan handuk mereka di jendela kamar, kemudian tidak mengganti handuk di lingkungan pesantren adalah hal yang lumrah. Jika mereka tidak meminjam, orang atau teman lain akan meminjam handuk mereka, dan terkadang mereka menggunakannya tanpa memberi tahu pemiliknya.

Dalam mencuci handuk sebaiknya para santri merendamnya terlebih dahulu menggunakan air panas karena hal ini dapat membunuh kuman bakteri yang menempel pada handuk kemudian setelah mandi handuk harus di jemur di bawah sinar matahari sehingga pada saat digunakan handuk dalam kondisi kering. ${ }^{27}$

7. Hubungan Kebersihan Kasur dan Sprei dengan Gejala Skabies di Pondok Pesantren Darul Hikam Kecamatan Rimbo Ulu

Berdasarkan analisis bivariat menggunakan uji Chi-square untuk mengetahui hubungan antara variabel kebersihan kasur dan sprei dengan gejala skabies di Pondok Pesantren Darul Hikam Kecamatan Rimbo Ulu diperoleh nilai $p=0,049<0,05$ yang diartikan bahwa ada hubungan antara kebersihan kulit dengan gejala skabies di Pondok Pesantren Darul Hikam Kecamatan Rimbo Ulu dan menunjukkan nilai prevalence ratio (PR) sebesar 0,400 dengan nlai $\mathrm{Cl} 95 \%$, menunjukkan bahwa nilai $\mathrm{PR}<1$ yang berarti kebersihan kasur dan sprei yang baik sebagai faktor protektif, hal ini juga dapat dilihat dari distribusi frekuensi yaitu sebanyak $55,6 \%$ santri memiliki kebersihan kasur dan sprei yang buruk.

Hal ini sejalan dengan penelitian Ridwan, dkk 2017 yang menyatakan bahwa terdapat hubungan antara kebersihan kasur dan sprei dengan kejadian skabies di Pesantren Darul Muhlisin Kota Kendari dengan $\mathrm{p}=0,005 .{ }^{5}$ Hasil penelitian yang sama juga didapatkan oleh Pita Ria Sonata yang menunjukkan bahwa signifikansi pvalue $=0,013(p<0,05)$, artinya ada hubungan antara kebersihan sprei dengan kejadian penyakit skabies di Pondok Pesantren Al-Hasani Komyos Sudarso. ${ }^{28}$

Skabies dapat menyebar melalui kontak kulit langsung atau melalui kontak tidak langsung dengan benda bersama (seperti pakaian, seprai, dan sarung bantal). Semakin banyak parasit yang dimiliki seseorang, semakin besar kemungkinannya untuk menyebar di lingkungan yang sama. ${ }^{29}$

Menjaga kebersihan tempat tidur (termasuk seprai, sarung bantal dan bantal) sangat penting untuk kesehatan pribadi, terutama kesehatan kulit. Maka dari itu mengganti seprei dan mengeringkan kasur setidaknya seminggu sekali. Setelah seminggu atau lebih, debu bisa menumpuk di kasur dan kutu bisa masuk ke pori-pori seprei. Virus, bakteri, parasit dan organisme lain dapat mencemari dan mempengaruhi kesehatan. ${ }^{30}$

Berdasarkan hasil wawancara dan hasil distribusi pertanyaan mengenai kebersihan kasur dan sprei menunjukkan bahwa sebagian besar santri sering tidur di kasur temannya dan tidak menjemur kasur minimal 2 minggu sekali dengan presentase $77,8 \%$, tidak mengganti sprei $49,2 \%$. Kemudian kasur yang digunakan 
untuk tidur santri di susun menjadi satu dengan kasur santri yang lainnya. Kasur dan bantal hampir tidak terkena sinar matahari, dan seprei yang dicuci dengan tidak bersih dapat menjadi tempat berkembang biaknya bakteri, kutu, dan bakteri yang dapat menyebarkan skabies pada santri. ${ }^{14}$

\section{KESIMPULAN}

Variabel yang berhubungan dengan gejala skabies di Pondok Pesantren yaitu kepadatan hunian, luas ventilasi, kebersihan kulit, kebersihan kasur dan sprei, sedangkan yang tidak memiliki hubungan yaitu penyediaan sarana air bersih.

\section{REFERENSI}

1. Suparmi, Supriatna. Faktor Risiko Kejadian Skabies Di Wilayah Puskesmas Olak Kemang Kota Jambi. J IIm Univ Batanghari Jambi [Internet]. 2015;15(2):87-93. Available from: htpp://ji.unbari.ac.id/index.php/ilmiah/article/view/185

2. Siregar GT. Pengaruh Penyuluhan Pencegahan Penyakit Skabies Terhadap Pengetahuan Santri Di Ponpes Al-Anshor Desa Manunggal Kecamatan Padang Sidempuan Tenggara Kota Padang Sidempuan Tahun 2014. Sci J STIKes PRIMA JAMBI. 2015;4(1):60-6.

3. Setiawan P, Kurniawan B. Pengaruh Personal Hygiene dalam Pencegahan Penyakit Skabies. Majority. 2016;5(5).

4. WHO. Skabies [Internet]. 2020 [cited 2020 Nov 15]. Available from: https://www/who.int.news-room/factsheet/detai/scabies

5. Akhwati RR, Sahrudin, Karma I. Hubungan pengetahuan, personal hygiene, dan kepadatan hunian dengan gejala penyakit skabies pada santri di pondok pesantren darul muklisin kota kendari 2017. J IIm Mhs Kesehat Masy [Internet]. 2017;2(6):1-8. Available from: http://ojs.uho.ac.id/index.php/JIMKESMAS/article/viewFile/2914/2173

6. Dinas Kesehatan Kota Jambi. Profil Dinas Kesehatan Kota Jambi Tahun 2014. 2014.

7. Tebo DKK. Profil Kesehatan Kabupaten Tebo 2015. Tebo; 2015.

8. Puskesmas Rimbo Bujang IX. Profil Puskesmas Rimbo Bujang IX 2020. Rimbo Ulu; 2020.

9. Pondok Pesantren Darul Hikam. Profil Pondok Pesantren Darul Hikam 2020. Rimbo Ulu; 2020.

10. Arifuddin A, Kurniawan H, Fitriani. Faktor Risiko Kejadian Scabies Di Rumah Sakit Umum Anutapura Palu. J IIm Kedokt [Internet]. 2016;3(3):40-59. Available from: http://jurnal.untad.ac.id/jurnal/index.php/MedikaTadulako/article/download/9274/7367

11. LeMone, Priscilla, Dkk. Buku Ajar Keperawatan Medikal Bedah. Vol.2 Edis. Jakarta: EGC; 2016.

12. Tansil, Sukmawati, Darmawan H. Ilmu Penyakit Kulit Dan Kelamin. Jakarta: Sagung Seto; 2016.

13. Djuanda. IImu Penyakit Kulit Dan Kelamin. Edisi.5. Jakarta: FKUI; 2010.

14. Sadidah HN. Faktor-Faktor Yang Mempengaruhi Kejadian Penyakit Kulit Skabies Pada Santri Mts Pondok Pesantren Ibnu Ajhari Kecamatan Tambelang Kabupaten Bekasi Tahun 2019. 2019; Available from: http://scholar.googleusercontent.com/scholar?q=cache:mmxv8jpW2ycJ:scholar.google.com/+hubungan+ faktor+sanitasi+lingkungan+dengan+gejala+skabies\&hl=id\&as_sdt=0,5\&as_ylo=2017\&authuser=4

15. Fitria N, Tosepu R, Kesehatan F, Universitas M, Oleo H, Kendari K, et al. Hubungan Sanitasi Lingkungan dan Higiene Perorangan Dengan Keluhan Penyakit Skabies Pada Anak-Anak di Panti Asuhan Amaliyah Kota Kendari Tahun 2019. 2020;1(03).

16. Nadiya A, Listiawaty R, Wuni C. Hubungan Personal Hygiene Dan Sanitasi Lingkungan Dengan Penyakit Scabies Pada Santri Di Pondok Pesantren Sa'Adatuddaren. Contag Sci Period J Public Heal Coast Heal. 
2020;2(2):99.

17. Kesmas. Syarat Sarana Penyediaan Air Bersih [Internet]. Indonesi Publich Health. 2017. Available from: http://www.indonesian-publichealth.com/syarat-sarana-penyediaan-air-bersih

18. Purnama SG. Diktat Dasar Kesehatan Lingkungan. Bali: Fakultas Kedokteran Universitas Udayana; 2018. 1-97p.

19. Farihah U, Azizah R. Faktor Sanitasi Lingkungan Yang Berhubungan Dengan Skabies Di Pondok Pesantren Qomaruddin Kabupaten Gresik. Str J IIm Kesehat [Internet]. 2017;31-8. Available from: https://media.neliti.com/media/publications/236552-faktor-sanitasi-lingkungan-yang-berhubun1cc3c9f8.pdf

20. Wulandari A. Hubungan Personal Hygiene Dan Sanitasi Lingkungan Dengan Kejadian Skabies Pada Santri Di Pesantren Ulumul Qur'an Kecamatan Bebesan Kabupaten Aceh Tengah. Glob Heal Sci. 2018;3(4):322-8.

21. Kementrian Kesehatan Republik Indonesia. Peraturan Menteri Kesehatan Republik Indonesia Tentang Pedoman Penyehatan dalam Rumah. Jakarta; 2011.

22. Sidhi AN, Raharjo M, Astorina N, Dewanti Y, Lingkungan BK, Masyarakat FK, et al. BAKTERIOLOGIS AIR BERSIH TERHADAP KEJADIAN. 2016;4.

23. Handari SRT, Yamin M. Analisis Faktor Kejadian Penyakit Skabies di Pondok Pesantren An-Nur Ciseeng Bogor 2017. J Kedokt dan Kesehat [Internet]. 2018;14(2):74-82. Available from: https://jurnal.umj.ac.id/index.php/JKK/article/viewFile/2734/2490

24. Makarim FR. 4 Jenis Penyakit Kulit yang Perlu Diwaspadai. 2021; Available from: https://www.halodoc.com/artikel/4-jenis-penyakit-kulit-yang-perlu-diwaspadai

25. Abdi H. Sabun Batang vs Sabun Cair, Ini Kelebihan dan Kekurangannya pada Kulit. 2019; Available from: https://hot.liputan6.com/read/4042127/sabun-batang-vs-sabun-cair-ini-kelebihan-dan-kekurangannyapada-kulit

26. Kesmas. Standar Personal Hygiene [Internet]. Indonesi Publich Health. 2017. Available from: http://www.indonesian-publichealth.com/standar-personal-hygiene/

27. Prasetyo D. 5 Cara Menjaga Kebersihan Handuk dari Kuman Penyakit. 2021; Available from: https://www.popmama.com/life/home-and-living/fx-dimas-prasetyo/cara-menjaga-kebersihan-handukkeluarga-dari-kuman-penyakit/3

28. Sonata PR. Hubungan Antara Personal Hygiene Santri Dengan Kejadian Penyakit Skabies Di Pondok Pesantren Al-Hasani Komyos Sudarso. 2014; Available from: http://repository.unhumpnk.ac.id/240/1/9. jurnal.docx

29. Din BCN, Sibuea S. Penatalaksanaan Penyakit Skabies Pada Laki-Laki Usia 42 Tahun Dengan Pendekatan Kedokteran Keluarga. Medula. 2020;10(2):241-50.

30. Irfan, Dilianty OM. Personal Hygiene and Scabies Incidence on Scavengers in Alak Lanfill Kupang City. Int $J$ Sci Basic Appl Res [Internet]. 2016;29(6):76-82. Available from: http://gssrr.org/index.php?journal=JournalOfBasicAndApplied 